\title{
Performance of Java Super Native Chicken and Catfish Floating Net Cage Reared Above the Former Pool of the Small Brick Industries
}

\author{
Ardi Novra ${ }^{1}$, Adriani $^{1}$, Fahmida Manin ${ }^{1}$, Lizawati $^{2}$ and Mursalin ${ }^{2}$ Eva Achmad ${ }^{2 *}$ \\ ${ }^{1}$ Faculty of Animal Science and CoE-HE SIFAS, Jambi University, Indonesia \\ ${ }^{2}$ Faculty of Agriculture and CoE-HE eMEDICAL, Jambi University, Indonesia \\ *Correspondent Author: Eva Achmad e-mail : evaachmad@unja.ac.id
}

\begin{abstract}
This fields experiment research aims to analyze the performance of integrated super-native chicken farms and catfish that are cultivated on the floating net cages (FNC) in the former ponds of the small brick industry in Jambi Province, Indonesia. The results showed that the production performance of Java Super Native Chickens (JSNC) was higher (FCR 2.3) than conventional farming (2,17-2,20), but economically feasible to develop (IOFC 1.17 and Profitability 16.7\%). Performance of FNC catfish that are cultivated directly under enlarged chicken coops has improved compared to the level of revenue cost ratio (RCR 1.26, average selling weight of 67 days 127.45 grams with a proportion number catfish feasible to sale $38.40 \%$, FCR (0.75) and IOFC 1.66. The results of this study indicate that there is a symbiotic mutualism between the two commodities, where the remaining feed of grower chickens that spill into floating net cages is an alternative source of catfish feed that is cultivated under the cage. Based on this research, it can be concluded that the integration between the two commodities is more profitable.
\end{abstract}

\section{Keywords: Native Chicken, Catfish, Small Brick Industry, Floating Net Cages, Integrated.}

\section{INTRODUCTION}

One of the potential economic activities causing disturbance of habitat and community microarthropods of land (abundance, composition, tropical diversity, distribution patterns and stability) is the brick industry [1]. As with other mining activities, clay mining activities in the brick industry can cause irreversible damages or once an area is opened, it will potentially be permanently damaged [2]. Mining activities have a major impact on the environment by losing the protective function of the soil due to the absence of canopy closure (resulting in disruption of other functions), loss of biodiversity (gene pool), degradation in watersheds, changes in land formation, increased erosion, and release heavy metals that can enter the aquatic environment [3]. The problems encountered in the restoration of ex-mining land are a) physical problems of the soil which includes the texture and structure of the soil (soil solum, compaction, stability and landform), b) soil chemical problems associated with soil reaction $(\mathrm{pH})$, lack of elements nutrients (nitrogen, phosphor calcium, and magnesium), and mineral toxicity, and c) biological constraints such as loss of vegetation cover and potential microorganisms that need to be overcome by improving soil conditions, selection of tree species, and the use of mycorrhea [4].

The exchange system reclamation model is the most inexpensive, easy, fast and efficient system on critical areas of ex-brick excavation [5]. This reclamation model is done by working on the former excavated soil and then planted pioneer plants that are easy to care for (bean stalks which, besides being easy and fast growing treatments, also effectively bind the air nitrogen to be stored in the soil so that the soil will be faster to rehabilitate itself, trees will benefit land rehabilitation activities, because they will enable a succession of "jump-starts", provide shelter, modify the extreme of land damage [6]. Restoration of damaged ecosystems according to Rahmawaty (2002) has a dual purpose, a) protective objectives namely improving land stability, accelerating land cover and reducing surface run off and soil erosion, b) productive goals that lead to increased soil fertility so that productive returns to plants that not only produce wood, but also nonwood 
products (rattan, latex, medicines, fruits etc.), and c) conservative goals for accelerating natural succession towards increasing biodiversity of local species (utilization of local potential plant species).

Technically, small brick excavation (SBE) ponds have sufficient quantity and quality of water suitable for the development of productive economic enterprises. The source of water comes from ground water (springs) and rainwater, causing a pool of water will be sufficiently available throughout the year with decent water quality because it does not experience pollution of hazardous substances because without chemicals and ferum content which causes acidic water [7]. The bricks industry businessman utilizes the SBE ponds as agricultural land (rice fields) and fisheries by taking into account the factors of labor use, length of land preparation, volume of fertilizer used, the location of the former bricks industry excavation land, marketing area [8]. The maintenance of fish in a former Lio soil excavation pond (making bricks) is an interesting thing, because there is no need to dig up the soil to make a fish pond [9]. Utilization for fish farming is more profitable because the cost of fishery production is cheaper and the depth of the former land of the brick industry excavation [8]. On the other hand, the use of land for food crops requires improvement of constraints, including liming and adding organic material, the destruction of lumps of padding, the use of mechanical and vegetative methods for erosion control [10].

The SBE ponds area also has the potential to be utilized for integrated cultivation through the development of livestock farming on floating net cages by following the working principle of the Longyam model (culture on ponds). Longyam is a combination of raising fish with livestock such as chickens, ducks or quails, where the cage is located above the pond as part of a farm that is commonly called the Integrated Farming System [11]. The Longyam cultivation system has several advantages, including a) efficient use of land and is economically more profitable, because farmers will get two results at once; b) fish feed efficiency, because fish feed can come from manure and leftover chicken feed (approximately 1-3\% of the feed given to chickens) that fall into the pond; c) chicken droppings that fall into the pond can also trigger the development of plankton which becomes fish food; d) Longyam system can significantly reduce the smell of the cage [12]. Longyam system will stimulate fish actively seeking and grabbing the fall of leftover food and feces that enter the pond. Because not all chickens will dispose of poop together, thus the waste will allow it to be eaten up, so that fish growth will be faster [11]. This fields experiment research aims to analyze the performance of integrated Super Java Native Chicken (SJNC) farms and catfish that are cultivated on the floating net cages (FNC) in the former ponds of the small brick industry in Jambi Province, Indonesia.

\section{MATERIAL AND METHODS}

This field experiment research was carried out for 60 days in the area of a SBE ponds in Pijoan Village, Jambi Luar Kota Subdistrict, Muaro Jambi Regency, Jambi Province, Indonesia. The research material was JSNC consisting of 300 three-day-old (DOC) JSNC, 50 breeder juvenile JSNC (3 months old), and 3,000 (750 seven-day-old catfish seeds/FNC). Chicken cages with a size of $3 \times 4$ meters were placed on a former quarrying brick pool, and at the bottom a FNC Catfish of size $2 \mathrm{x}$ 4 meters ( 750 catfish seeds/FNC) was placed as shown in Figure 1.

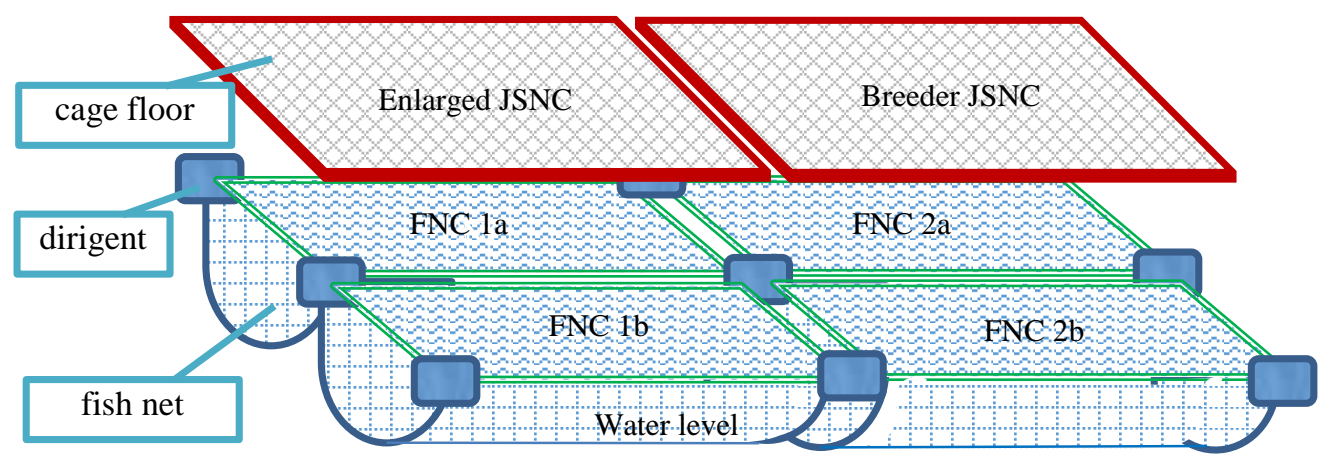

Figure 1; Design of Treatment in Field Research

Materials and equipment used consisted of commercial feed (according to the period of rearing native chickens and catfish), feed scales and chicken livestock as well as chicken feed and drinks. The study was carried out in stages with the importation of livestock and fish at 
different times so as to achieve the same harvest age of 60 days (see Table 1 ).

Table 1. Stages of conducting research and treatment in JSNC and FNC catfish

\begin{tabular}{|c|l|c|l|}
\hline \multicolumn{2}{|c|}{ JSPC treatments } & \multicolumn{2}{c|}{ FNC Catfish treatments } \\
\hline Days & Activities & Days & Activities \\
\hline $1-7$ & DOC raising in a heating box & 1 & Spreading fish seeds \\
\hline 7 & Transfer the chicken to the cage & $2-7$ & Fish adaptation period \\
\hline $7-21$ & Rearing children in cages & $7-33$ & Rearing growth period \\
\hline $22-60$ & Raising of chicken enlargement & 33 & First phase sample weighing \\
\hline 60 & Harvest and final weighting & 60 & Weighing selling weight \\
\hline
\end{tabular}

Performance appraisal indicators in the study consisted of technical performance namely feed conversion rate (FCR), and daily body weight gain (DGR), and economic performance namely income over feed cost (IOFC) and revenue and cost ratio (RC Ratio), using the following formula;

1. Feed convertion rate

$$
\mathrm{FCR}=\frac{\text { Feed consumption }(\mathrm{kg})}{\text { Final weight }(\mathrm{kg})}
$$

2. Daily gain rate

$$
\operatorname{DGR}(\%)=\frac{\text { Final weight }- \text { Initial weight }}{\text { Ages }}
$$

3. Income over feed cost

$$
\mathrm{IOFC}=\frac{\text { Final weight } \mathrm{x} \text { Meat price }(\mathrm{IDR})}{\text { Total consumption } \mathrm{x} \text { Feed price }(\mathrm{IDR})}
$$

4. Profitabilty rate or revenue cost ratio :

$$
\mathrm{RCR}=\frac{\text { Total revenue }}{\text { Total cost }} \times 100 \%
$$

To assess whether the performance was successful or not, a comparison was made between the results of the study with cultivation in conventional locations.

\section{RESULT AND DISCUSSION}

\subsection{Small Bricks Industries and Land Degradation}

Red brick is an artificial stone made from a material made by humans so that it has properties such as stone and this can only be achieved by heating (burning) or by chemical works. Red brick is one of the elements in building construction made of clay plus water with or without other mixed materials through several stages of work, such as digging, processing, printing, drying, burning at high temperatures to ripen and change color, and will harden like a rock after it has been cooled so that it cannot be destroyed again when immersed in water. Whereas based on Wikipedia, 2013 brick is one of the materials as a material for making walls made from clay which is burned to reddish color. The production process of bricks from the excavation of land until it is ready to sell takes a relatively long time and even monthly as shown in Table 2.

Table 2. Types of Activities and Estimated Time Period Required in the Brick Production Process

\begin{tabular}{|c|l|c|c|}
\hline \multirow{2}{*}{ No } & Activities & \multicolumn{2}{|c|}{ Duration (days) } \\
\cline { 2 - 4 } & & Dry season & Rainy season \\
\hline 1 & Land Excavation / Procurement & 1 & 1 \\
\hline 2 & Mixing of Printed Raw Materials & 2 & 2 \\
\hline 3 & Printing & 4 & 6 \\
\hline 4 & Drying & 14 & 4 \\
\hline 5 & Compilation of Burn stoves & 4 & 5 \\
\hline 6 & Combustion & 3 & 3 \\
\hline 7 & Cooling down & 5 & 3 \\
\hline 8 & Demolition & 3 & 21 \\
\hline
\end{tabular}




\section{Total Duration}

Sources: Interview with the small bricks industry actors (2015)

The development of the people's brick industry in Jambi Province is quite rapid along with the increase in demand which is driven by the increasing development activities and regional economy. This industry, which is classified as Small and Medium Enterprises, is generally a household industry that has developed in many sub-urban and buffer zones of Jambi City. In 2012 in the sub-urban area of Jambi City there were 180 brick ward units spread across 36 production centers, while in the buffer zone, namely the Muaro Jambi District, there were 271 ward units. If each ward unit can absorb around 15 workers, it is estimated that in both regions it can absorb 6,765 workers. One of the buffer areas that become centers of SME bricks is the Jambi Luar Kota District (Jaluko) which is geographically bordered directly by the City of Jambi and is a Center Point of the East and West Roads,

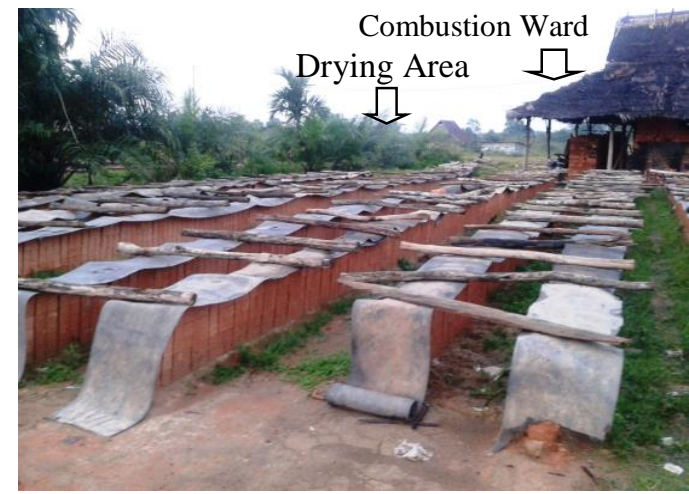

36

45

making it economically one of the centers of economic growth.

In contrast to the people's brick industry in some areas such as West Sumatra, the process of land exploitation in the brick industry in Jambi is similar to open coal mining techniques, namely mining with a mining process begins with peeling off the overburden. Open pit mining can totally change both the climate and the soil as a result of all soil layers above the mineral deposits being removed so that vegetation is indirectly lost (water regulating functions, erosion control, flooding, carbon sequestration, oxygen suppliers and regulators temperature) and can also cause socioeconomic changes in the community around the mining area. In the brick industry there are basically 3 (three) other usage groups with different environmental damage as shown in Figure 2.

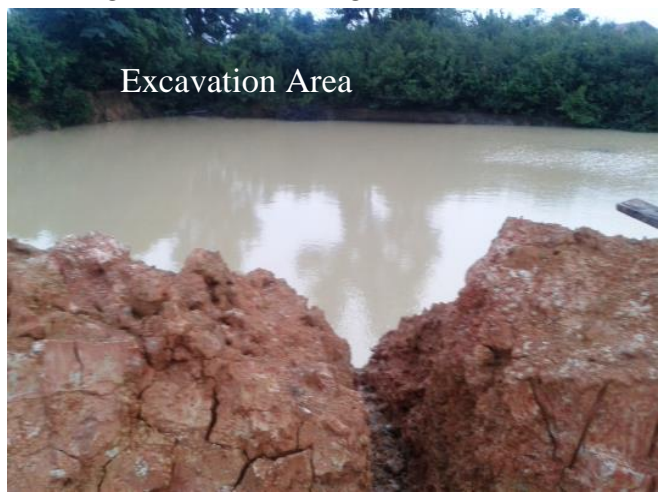

Figure 2. Land areas of small bricks industry

In a brick industry, the location of land is grouped into burning areas or called bangsal with simple buildings, drained land and excavated land. The first two land groups not only caused vegetation loss but also hardened by brick loads and stamping during transportation. On this land, the reclamation model of the exchange system is the most inexpensive, easy, fast and efficient system on critical land that has been extracted from red brick raw material [5].

\subsection{Performance of Java Super Native Chicken above the SBE pond}

Super Javanese chicken or abbreviated as Joper or also often referred to as super village chicken is the result of cross-breeding between male chickens with laying hens [13]. Cultivation of native chicken based on its purpose consists of 2 types, namely meat production and layer breeding (egg production). But this research focused on performance discussion as the first purpose because the proportion of chicken breeds that have been produced until the end of the study is relatively very small. Super native chicken (camphor) or Joper (Jowo Super) has a faster growth rate, so that it can be harvested at the age of 50-60 days, with a body weight of about 0.8 to 1.0 $\mathrm{kg} / \mathrm{head}$, according to the desired weight of the restaurant. Having better genetic makeup than ordinary native chickens, super native chickens are actually more profitable and promising because in the period of harvest maintenance only takes 55-60 days. The standard mortality rate ranges from $5-10 \%$ with uniformity when ready to harvest, reaching 85 percent and an average weight of $0.8-1 \mathrm{~kg}$. The performance of the first period of super native chicken rearing in the cultivation business of 280 is presented in Table 3 . 
Table 3. Performance of JSNC production that is kept above the former small brick excavation (SBE) pond

\begin{tabular}{|c|c|c|c|c|}
\hline No & Variable & Achievements & Standard & Noted \\
\hline 1 & Average harvest weight $(\mathrm{kg})$ & 0,84 & $0,8-1$ & Standard range \\
\hline 2 & Mortality rate $(\%)$ & 12,1 & $5-10$ & Higher \\
\hline 3 & Feed conversion & 2,3 & $2,17-2,20$ & Low efficient \\
\hline 4 & Total cost (IDR) & 8.627 .000 & 7.911 .600 & Higher \\
\hline 5 & Cost/Box (IDR/100 heads) & 2.270 .263 & 2.082 .000 & Higher \\
\hline 6 & Revenue (IDR) & 10.063 .800 & 12.312 .000 & Lower \\
\hline 7 & Net Revenue (IDR) & 1.436 .800 & 4.400 .400 & Lower \\
\hline 8 & Net Revenue/head (IDR) & 3.781 & 11.580 & Lower \\
\hline 9 & Net Revenue/head/days (IDR) & 63 & 193 & Lower \\
\hline 10 & Benefit cost ratio & 1,167 & $>1$ & Feasible \\
\hline 11 & Profitabilty (\%) & 16,7 & $>14 \%$ & Feasible \\
\hline
\end{tabular}

Sources: Data processing, 2017

Technically, Java Super Native Chicken (JSNC) farming above the former SBE pond has a low performance compared to conventional or general enlargement business standards. The JSNC or Joper (Jowo Super) has a faster growth rate, so that it can be harvested at the age of 50-60 days, with a body weight of $0.8-1.0 \mathrm{~kg} / \mathrm{head}$, according to the desired weight of the restaurant $[14$

]. The final weight obtained is still within the standard limit but close to the minimum weight stated in the cultivation instructions, while the consumption of the ration given is as needed. This shows that technically the cultivation business has a low level of efficiency and is seen from the higher feed conversion rates (2.3). The performance of Java Super native chicken is daily consumption of 43.27-44.00 grams/head, daily body weight gain of 514.15-527.61 $\mathrm{mg} /$ head, and feed conversion of 2.17-2.20 [15]. Higher feed inefficiency and a higher mortality rate will have an impact on the low economic efficiency of the Java Super native chicken farming business and profitability.

Even though economically the performance of the JSNC rearing business is still feasible but it provides relatively low returns. If calculated the investment value then benefit cost ratio (BC) is expected to be negative. Expenditure that is higher than the standard and vice versa smaller receipts than the standard causes a low level of profit. The low revenue is due to the high mortality rate (volume) and the low selling price factor. The actual harvest was carried out after Idul Fitri (moeslim holiday) causing an ideal selling price of IDR $42,000 / \mathrm{kg}$ has decreased dramatically to IDR $36,000 / \mathrm{kg}$. This indicates that the time factor (DOC revenue) must also be taken into account in order to obtain the right time to sell, namely when prices are high due to high demand pressure (in this case before
Eid). On the other hand, rising costs due to sales delays because in the early days of Eid, poultry that are kept are not absorbed by the market and during the additional time of cultivation the cost of feed must still be incurred.

The JSNC cultivation for breeding purposes is only able to lay eggs first at the age of 7-8 months which is longer than the ideal age of 5-6 months. The average weight of adult chicken (parent) 1,960.2 grams with egg weights 48.71 grams. Hatchability using a hatching machine is lower $(50 \%)$ than naturally (parent) which reaches $80 \%$ with an average hatching weight of 31.16 grams. In the economical aspect, intensive broodstock cultivation is not feasible because the production value cannot cover the cost of chicken feed. Temporary conclusions on the two cultural goals of Java Super native chickens indicate that economically cultivation for meat production is more feasible than for the purpose of eggs production. This interim conclusion is reinforced by the impact of native chicken farming on the performance of catfish that are kept under chickens cages.

\subsection{Performance of Catfish Floating Net Cages (FNC)}

Utilization of integrated ex-coal mining ponds (EEP) in an integrated manner between Java Super native chicken farming and catfish FNCs aims to optimize the mutually beneficial relationship (symbiosis of mutualism) between the two types of commodities. The coolness of the cage is expected to be able to encourage the growth rate of poultry and spilled feed can be a source of additional feed for catfish. Measurement of productivity of catfish farming is done in 2 stages, namely at the age of 33 and 69 days with the average weight of fish in each FNC unit presented in Figue 3. 


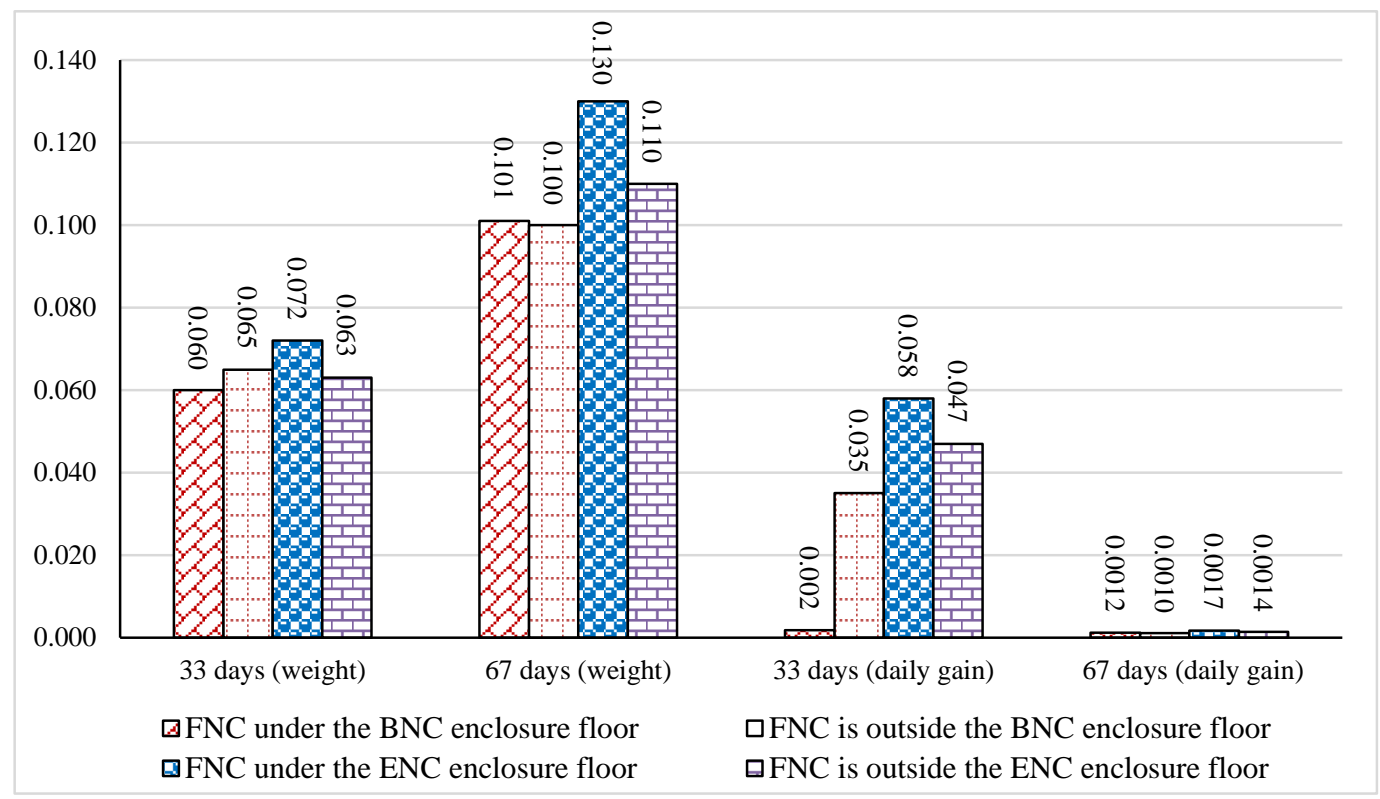

Figure 3. Production achievement of the FNC Catfish

As for consumption, which is desired by the market which weighs 3 ounces $-1 \mathrm{~kg}$ because of the size of more than $1 \mathrm{~kg}$, it is rather difficult for processing, usually found in conditions that have been filled [16]. Achievement of body weight of FCN Catfish placed under the chicken coop for the purpose of meat production at both the age of 33 days and 67 days on average is higher than in other placements. Specifically for FCN Catfish under the juvenile chicken coops that are prepared for the production of seed eggs which are placed on the outside of the floor of the cage have a higher body weight compared to the inside. The opposite is true for FCN catfish farming under chicken coops for the purpose of meat production, the inner FCN catfish are higher. The same indication is also strengthened by comparing the daily gain rate of FCN catfish from 33 days to 66 days and result of sorting at the age of 67 days of harvest is not all pating fish have a selling weight that meets the eligibility standards with varying amounts for each FCN placementas shown in Figure 4.

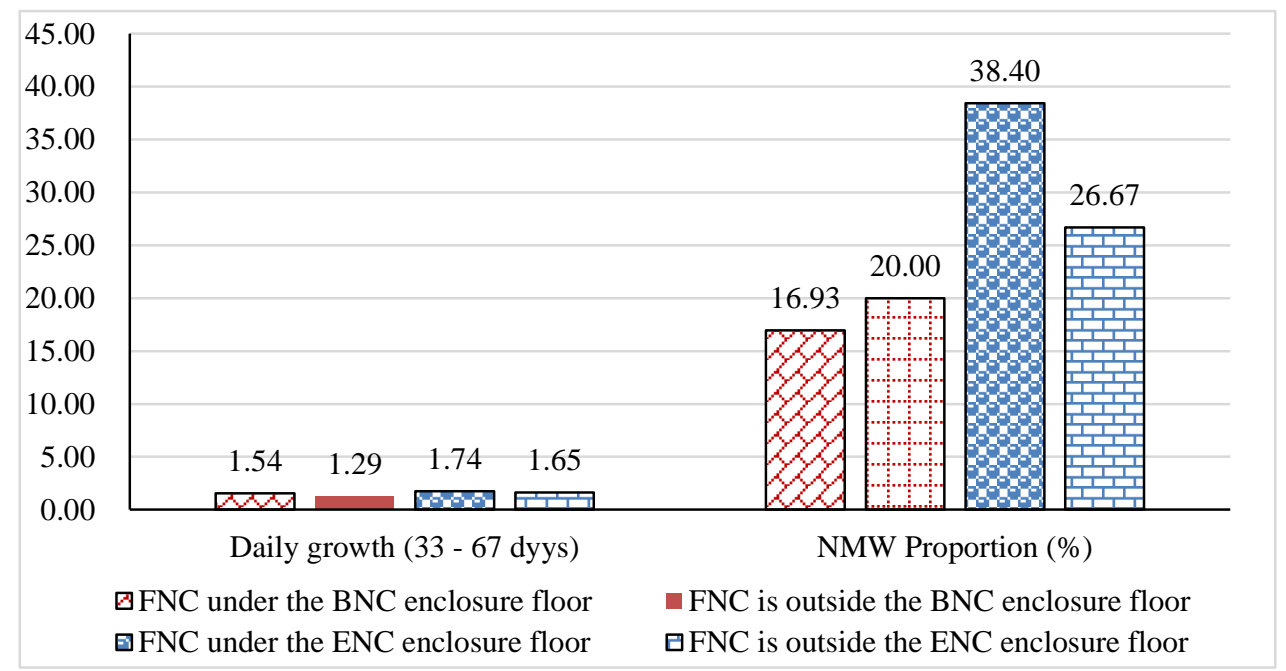

Figure 4. Daily FNC Catfish growth (\%) and proportion of NMW (\%)

The best production performance was achieved by the catfish FCN that was cultivated just under the ENC cage floor with a daily growth rate of $1.74 \%$ over the 33-67 day age period. This good production indicator can also be seen from the proportion of the number of catfish that has reached the feasibility of selling age (5 heads $/ \mathrm{kg}$ ) around $38.40 \%$ or 288 out of 750 scattered catfish seedlings. On the other hand, the catfish FNC that was cultivated under the outside BNC cage had the worst performance (daily growth 1.29) but the proportion of NMC was higher $(20.00 \%)$ compared to the catfish FNC right under the BNC 
cage which only reached $16,93 \%$. This selling weight indicator is based on market demand, especially food stalls such as Padang Rice and Catfish Pecel as the main consumers that for appropriate and affordable consumer services, the ideal body weight of catfish is 1 $\mathrm{kg}$ for 7 fish (average 150 ounces/fish).

Differences in daily growth rates and NMC proportions indicate that in integrated aquaculture between JSNC and FNC Catfish the placement of FNC right under the cage is better to improve business efficiency. The remaining feed for enlarged SNJV children which has a protein content that is almost the same as fish feed will provide a better growth rate for catfish. Unlike the rest of the adult JSNC feed with lower protein content and less feed spills, it is ineffective as an additional feed for catfish. The better growth of catfish in the FNC on the outside of the cage compared to the one right under the adult SNJV cage is thought to be due to contamination of water due to chicken manure raised on it.

The achievement of different aquaculture production will directly impact the business performance of catfish FNC, and as with poultry, the business efficiency of FNC Catfish is also greatly influenced by the use of feed, both technically and economically. The performance results of the calculation of technical efficiency illustrated through the feed conversion indicator (FCR) and economic efficiency through the ratio of income to feed costs (IOFC) are presented in Table 4. In contrast to the JSNC business, the conversion rate of FNC catfish rations could potentially be smaller $(\mathrm{FCR}<1)$ because in the ponds there are alternative feed sources both from nature and spills of leftover feed and chicken manure. The level of efficiency of FNC Catfish rations (0.86) placed directly below (insite) the enlarged JSNC cage floor is better than other placements. Achievement of higher selling weight (harvest) and followed by a low level of feed consumption, the total revenue from the cultivation of FNC Catfish directly under the enlarged SNJV floor has greater ability to cover the cost of feed (IOFC 1.66). Feed costs are the largest cost component that reaches $60-70 \%$ of the total production costs of poultry and fish (Anggitasari et al, 2016). The IOFC values from the analysis in Table 3 indicate that receipts from all treatment placements have the ability to cover feed costs (IOFC > 1), but do not guarantee business feasibility when calculating other input costs, as presented in Table 5.

Table 5. Performance of catfish farming FNC in the Former Pool of Small Brick Industry

\begin{tabular}{|c|c|c|c|c|c|}
\hline \multirow{2}{*}{ No } & \multirow{2}{*}{ Variables } & \multicolumn{2}{|c|}{ JSNC Breeding } & \multicolumn{2}{|c|}{ JSNC Enlarged } \\
\hline & & Insite & Outside & Insite & Outside \\
\hline \multirow[t]{4}{*}{1} & Revenue (IDR 000) & & & & \\
\hline & Firsts stage sales & 406,40 & 480,00 & 921,60 & 640,00 \\
\hline & Second stage sales & 676,78 & 648,38 & 621,33 & 645,29 \\
\hline & Total Revenue (TR) & $1.083,18$ & $1.128,38$ & $1.542,93$ & $1.285,29$ \\
\hline \multirow[t]{6}{*}{2} & Cost (IDR 000) & & & & \\
\hline & Catfish feed & $1.049,26$ & $1.031,91$ & 927,76 & 994,17 \\
\hline & Catfish Seeds & 150,00 & 150,00 & 150,00 & 150,00 \\
\hline & Others & 150,00 & 150,00 & 150,00 & 150,00 \\
\hline & Total Cost. (TC) & $1.349,26$ & $1.331,91$ & $1.227,76$ & $1.294,17$ \\
\hline & Feed cost proportion (\%) & 77,77 & 77,48 & 75,57 & 76,82 \\
\hline 3 & Net Benefeit (TR - TC) & $-266,08$ & $-203,53$ & 315,17 & $-8,89$ \\
\hline 4 & Profitability (RCR) & 0,80 & 0,85 & 1,26 & 0,99 \\
\hline
\end{tabular}

Sources: Data processing, 2017.

Without calculating the investment cost (fix cost) of catfish FNC cultivation, the proportion of feed costs to operational costs has exceeded the ideal proportion $(60-70 \%)$ and is even greater than revenue except for placing FNC directly under the enlarged JSNC cage. This means that only the integration of catfish FNC and enlargement JSNC models are still financially viable with an RCR of 1.26. The short-term profit or production cycle obtained in catfish agribusiness is IDR 0.278 for every IDR issued or RCR of 1,278 [17]. Even though it is financially feasible, FNC catfish culture placed directly under the enlarged JSNC cage floor is still risky if investment costs are taken into account. For this reason, efforts to improve the cultivation system are still needed, such as saving the cost of feed. Efforts to improve IOFC performance can be done through reducing the dependence of commercial feed or using alternative feed so as to reduce the cost of feed without ignoring the nutritional needs of catfish. 


\section{CONCLUSION AND RECOMMENDATION}

\subsection{Conclussion}

Based on the results of the study, it can be concluded that the integration of Java Super Native Chicken (JSNC) farming business and catfish culture of floating net cage (FNC) systems has the potential to be developed in the utilization of small ponds used in the excavation of small brick industries. The production performance of Java Super Native Chickens (JSNC) was higher (FCR 2.3), but economically feasible to develop (IOFC 1.17 and Profitability 16.7\%). Performance of FNC catfish that are cultivated directly under enlarged chicken coops has improved compared to the level of revenue cost ratio (RCR) 1.26, average selling weight of 67 days 127.45 grams with a proportion of feasible sale $38.40 \%$, FCR 0.75 , and IOFC 1.66.

\subsection{Recommendation}

Even though it is financially feasible, FNC catfish culture placed directly under the enlarged JSNC cage floor is still risky if investment costs are taken into account. For this reason, efforts to improve the cultivation system are still needed, such as saving the cost of feed. Efforts to improve IOFC performance can be done through reducing the dependence of commercial feed or using alternative feed so as to reduce the cost of feed without ignoring the nutritional needs of catfish.

\section{ACKNOWLEDGMENTS}

This research for this paper was financially supported by the Educational Fund Management Institution, Ministry of Financing Republic of Indonesia through Competitive Research Innovative and Productive (RISPRO Competitive) scheme 2016 with contract number 649/LPDP/2016.

\section{REFERENCES}

[1] J. Siti, 2008. Soil microarthropod community in land rehabilitation of former extinguished bricks, Available in http://etd.repository.ugm.ac.id/index.php?mo $\mathrm{d}=$ penelitian detail\&sub= $\underline{\text { PenelitianDetail\&act }=\text { view }} \&$ typ $=$ html\&buku $\mathrm{id}=3814$ Accessed May, $20^{\text {th }} 2015$.

[2] Suprapto, 2011. Legal aspects of coal mining reclamation: study in Satui Tanah Bumbu District, Syiar Hukum Journal, 13(3): 195201.

[3] Rahmawaty, 2002. Restoration of the former mining area based on ecological rules, Faculty of Agriculture, University of North Sumatra Medan, Indonesia.

[4] A. D. Bradshaw, 1984. Ecological principles and land reclamation practice, Landscape planning journal. 11(1): 35-48. DOI: https://doi.org/10.1016/0304-3924(84)90016$\underline{9}$

[5] H. Hidayat, M. Indriastuti, F. Syafrina, S. D. Arismawati, and B. Sembodo, 2006. Critical land reclamation model in the former areas of stone quarrying, Department of forest management and resources conservation, Faculty of Forestry, Gajah Mada University, Yogyakarta.

[6] A. E. Lugo, 1997. The apparent paradox of reestablishing species richness on degraded lands with tree monocultures. Forest Ecology and Management, 99 (1-2): 9-19.

[7] A. Novra, J. Andayani and I. Sulaksana, 2019. Strengthening the households economic resilience in the small brick industry through the oyster mushroom cultivation business, Abdimas Mahakam Journal 3(02): 97-108.

[8] N. D. Fajri, 2011. The Utilization of the former land of the brick industry excavation in Jambidan Village, Banguntapan District, Bantul Regency. Thesis, Yogyakarta State University, Yogyakarta.

[9] MoA (Ministry of Agriculture). 2015. Catfish cultivation in former red brick excavation ponds, Surya Mina Farm (SMF) Articles Sleman, Available in: http://www.bibitikan.net/ budidaya-ikanpatin-pada-bekas-galian-bata-merah/, Accessed May, $20^{\text {th }} 2015$.

[10]R. Pratiwiningtyas, 2012. Conformity of the land of the former bricks for food crops in Ngampon Hamlet, Sitimulyo Village, Piyungan District, Bantul Regency. Thesis, Faculty of Social Sciences, Yogyakarta State University, Yogyakarta.

[11]B. Sutrisno, 2012. Longyam cage on ponds. Bumi Ternak Klaten. Available: https://bumiternakbetha.blogspot.com/2012/11/longyamkandang-di-atas-kolam.html Accessed: November, $16^{\text {th }} 2012$.

[12] First Livestock, 2016. Technical consultation: Held chicken on the nice pool or not? Available:

https://www.ternakpertama.com/2016/12/kon sultasi-teknis-kandang-ayam-diatas-kolambagus-atau-tidak.html, Accessed: December, $10^{\text {th }} 2016$.

[13] Ayobudidaya.com, 2015. How to raise Super Jowo Native Chicken, cages and seedling prices. Available: https://ayobudidaya.com/peternakan/carabeternak-ayam-joper/ Accessed: October, $09^{\text {th }}$

[14] Berlianegara, 2013. The Key to the Success of Javanese Super Native Chicken. Available: https://www.ayamkampungku.com/ayamjaw asuper, Accessed: January, 22 2013. 
[15] N. Rahmawati and F. Megaaprilia, 2017. Effect of dosage and method of giving turmeric flour to the performance of Javanese Super

[16] S. Untung, 2018. Catfish cultivation, farmers' interests seeds, meat become the mainstay of Japanese Resto, Available: https://siuntung.com/2018/10/29/ budidayaikan-patin-bibit-diminati-petani-daging-jadiandalan-resto-jepang/. Accessed: October, $28^{\text {th }} 2018$

[17]F. Sutarni and B. Unteawati, 2016. Analysis of short-term income freshwater fishery agribusiness specialty swimming Catfish in Central Lampung, National Seminar on Agricultural Technology Development Proceedings, Lampung State Polytechnic. September $8^{\text {th }} 2016$ p: $315-326$. 
Appendix 1. Research Activity
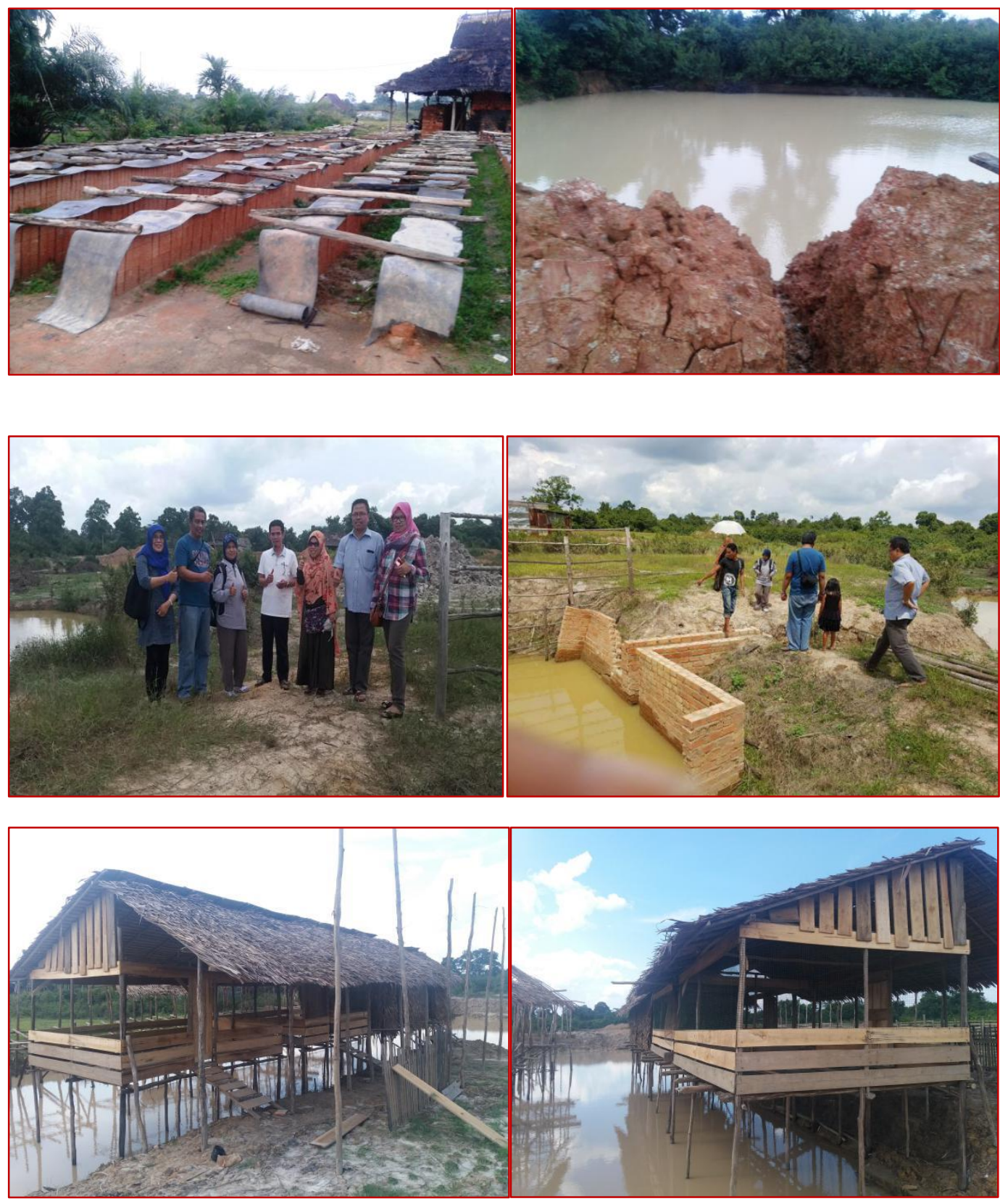